\title{
Leiomyoma of Vagina- A Case Report
}

\author{
Sultana $\mathrm{N}^{1}$, Ara $\mathrm{F}^{2}$, Akhtar $\mathrm{A}^{3}$, Haque $\mathrm{F}^{4}$
}

\begin{abstract}
Abastract
A 35 years old lady came from Borobari, Gazipur was admitted in the gynae. department of TMMC Hospital with mass in the vagina for 9 months, irregular per vaginal bleeding and dyspareunia for 1 month. Examination revealed an irregular solid mass arising from the posterior vaginal wall, which was ulcerated superficially. After conservative treatment, excision biopsy was taken and histopathology report revealed leiomyoma of the vagina. The case was managed surgically alone.
\end{abstract}

Key word-Vagina, Leiomyoma.

\section{Introduction}

Leiomyoma is a common benign tumour of pelvic organ. It is essentially composed of smooth muscle tissue although there is variable amount of fibrous tissue as well. In case of reproductive tract the common site is uterus. But it may develop in the cervix, ovary, fallopian tubes and vagina. Vagina is very unusual site for leiomyoma. In case of vagina it usually occurs in outer coat of vagina or from para colpos.

\section{Case report}

A 35 years old lady was admitted in the gynae. department of Tairunnessa Memorial Medical College Hospital with growth in the vagina for 9 months, irregular per vaginal bleeding and dyspareunia for 1 month. According to the statement she was normally menstruating woman. She noticed a small growth in the vagina, which was gradually increased in size. She also complained irregular per vaginal bleeding and dyspareunia for 1 month.

On admission, physical examination disclosed an essentially healthy appearance and normal vital signs. Pelvic examination disclosed that there was a solid irregular non-tender mass measuring $3 \mathrm{~cm} \times 4 \mathrm{~cm}$ in size arising from the middle of the posterior vaginal wall which was ulcerated superficially. Uterus was normal in size, cervix was apparently healthy and fornices were free. Rectal mucosa was free on per rectal examination. She gave no remarkable medical and surgical past illness.

All necessary investigations including USG of lower abdomen were done. All reports were found within normal limit except ESR which was $50 \mathrm{~mm}$ in 1 st hour

1. Corresponding Author: Dr. Nahid Sultana M.B.B.S., F.C.P.S Associate Professor \& Head of the Department of Obstetrics \& Gynaecology Tairunnessa Memorial Medical College.

2. Dr. Ferdous Ara M.B.B.S., F.C.P.S Assistant Professor of the Department of Obstetrics \& Gynaecology, Delta Medical College, Mirpur, Dhaka.

3. Dr. Ayesha Akhtar M.B.B.S., F.C.P.S Assistant Professor of the Department of Obstetrics \& Gynaecolog Tairunnessa Memorial Medical College.

4. Dr. Farzana Haque M.B.B.S. F.C.P.S Consultant 250 Bed District Hospital, Moulobhi Bazar.
Initially a short course of conservative treatment was given to control secondary infection with ciprofloxacin, metronidazole and antifungal drugs. After subsidence of local infection a biopsy was taken from the growth and histopathology report revealed leiomyoma of the vagina. Then the patient was finally treated by local excision of the entire growth. The histopathology of excised tissue finally concludes the leiomyoma of Vagina, the patient made an uneventful immediate post operative recovery. (Fig-1 A \& B)

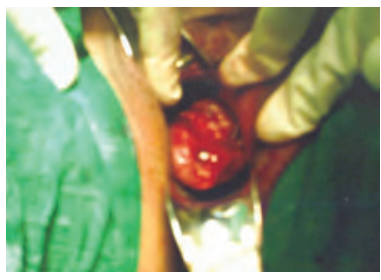

Leiomyoma of the vagina $(\mathrm{A})$

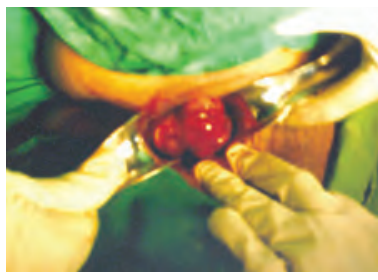

Leiomyoma of the vagina (B)

\section{Discussion}

Benign vaginal tumours are uncommon, but it occurs in the vaginal wall and includes myoma, fibromyoma, neurofibroma, papilloma, myxoma and adenomyoma ${ }^{1}$. Benign neoplasm of the vagina may be sessile or pedunculated. Some are para vaginal rather than vaginal, in that they arise from tissue in the para colpos. They can reach large dimensions and can extend into the broad ligament and into the ischiorectal fossa ${ }^{2}$.

Leiomyoma in the vagina is very occasional. It arises beneath the vaginal epithelium ${ }^{3}$. Leiomyoma is commonest of all tumour found in uterus of $20 \%$ woman over $30 \mathrm{yrs}$ of age. Leiomyoma of skin, stomach and intestine also not uncommon. A Leiomyoma is composed of whorled of smooth muscle cells interspersed among which there is a variable amount of fibrous tissue $^{4}$. Factors that initiate leiomyoma are not known. Ovarian sex steroids are important for their growth. Leiomyoma rarely develops before menarche and after menopause unless stimulated by exogenous hormone. Leiomyoma enlarged dramatically during pregnancy. It has increased level of oestrogen and progesterone receptors compared to other smooth muscle cell. Leiomyoma also has high level of growth factor that stimulates the production of fibronectin and collagens, major component of extracellular matrix that characterized these lesions ${ }^{5}$.

Small leiomyoma usually symptom less unless they become ulcerated or infected; they cause contact bleeding, discharge and irregular per vaginal bleeding. Large tumours cause dyspareunia, infertility, bladder irritability, rectal pressure and tenesmus and obstructed labour. Local excision is generally indicated. This is usually easy but can be very difficult if the tumour is large, vascular and extending in to the broad ligament ${ }^{2}$. 


\section{References}

1. MacLean AB .Benign disease of Vagina, Cervix and Ovary .In; Edmonds DR editor. Dewhurst's Textbook Of Obstetrics And Gynaecology For Postgraduates .6th edition. London .Blackwell Science Ltd. 1999.

2. Jeffcoate N.Tumours of the Vagina. In ;Jeffcoate N.Editor .Jeffcoate's Principles of Gynaecology .Arnold London 6th editition .2001.439-443.

3. Benign tumours, cysts and malformations of the Genital tract .In: Campbell S. Monga A. Editors. Gynaecology By Ten Teachers, 7th. ed. Elsevier Limited 2005.
4. Moore J.G. Nelson A.L. Congenital Anomalies and Benign Condition of the Uterine Corpus and Cervix. In; Hacker N.F Moor J.G. Gambone J.C. Editors. Essential of obstetrics and Gynecology. 4th edition. Elsevier INC.2004.268-276.

5. Zuckerman M. structure and effects of some Common Neoplasms. In; Walter J.B. Talbot IC. Editors. Waller and Israel General pathology. Pearson professional Limited 1996.435-470. 